\title{
Effectiveness of strychnine bush extract (Strychnos ligustrina Blume) on the prevalence and survival rate of Dumbo catfish (Clarias gariepinus) infected by Aeromonas hydrophila
}

\author{
Anis Zubaidah ${ }^{1, a,{ }^{*}}$, Sri Samsundari ${ }^{1, b}$, Hidayaturrahmi ${ }^{2, c}$ \\ ${ }^{1}$ Fisheries Department, Faculty of Agriculture and Animal Science, University of Muhammadiyah \\ Malang, Indonesia. \\ ${ }^{2}$ State Vocational High School 1 Lingsar, Lombok Barat, Indonesia \\ aaniszubaidah@umm.ac.id bsamsundari@umm.ac.id chidayaturrahmi0@gmail.com
}

${ }^{*}$ Corresponding author

\section{ARTICLE INFO ABSTRACT}

\section{Keywords:}

Aeromonas hydrophila

Clarias gariepinus

Prevalence

Strychnine bush

Survival rate
One of the problems of intensive catfish culture is the attack of Motile Aeromonas septicemia disease caused by Aeromonas hydrophila bacteria. To prevent it is necessary to prevent the use of natural antibiotics that is strychnine bush extract. The purpose of this research is to know the ability of strychnine bush extract (Strychnos ligustrina, Blume) to inhibit the growth of $A$. hydrophila bacteria and its effect on prevalence and survival rate in Dumbo catfish (Clarias gariepinus). The method used in this research is the exsperimen method by using complete randomized design with different doses of treatment (P1: $6 \%)$, (P2: 12 \%), (P3: 18 $\%),(\mathrm{P} 4: 24 \%)$ and (P5: $30 \%)$, each treatment was repeated 3 replications. The results showed that the giving of strychnine bush extract with different concentrations had a very significant effect on the width of the $A$. hydrophila bacterial resistance zone. The highest inhibition of treatment P5 with $8.29 \mathrm{~mm}$ inhibition power. In prevalence of dumbo catfish, treatment highest dose P5 with prevalence value equal to $40 \%$. In the survival rate of Dumbo catfish with the giving of strychnine bush extract have a very real effect, the highest synthesis of treatment P5 with $90 \%$. This study resulted in the conclusion that as for the higher inhibition power dose strychnine bush extract is used then the higher the power inhibition.
How to cite:

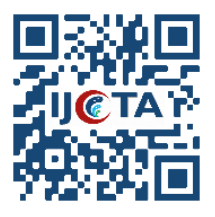

Zubaidah A, Samsundari S, Hidayaturrahmi. 2019. Effectiveness of strychnine bush extract (Strychnos ligustrina, Blume) on the prevalence and survival rate of Dumbo catfish (Clarias gariepinus) infected by Aeromonas hydrophila. IJOTA. 2(1): 1-8 DOI: 10.22219 /ijota.v2i1.5601

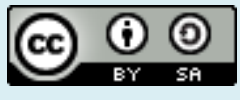

\section{Introduction}

Dumbo catfish (Clarias gariepinus) is a freshwater fish commodity with good prospect for cultivation. This fish is easy to breed, grow relatively fast, and is tolerant to poor water \& environment conditions (Shrestha and Pant, 2012). The rapid development of catfish farming business and intensive cultivation makes the fish more susceptible to bacterial diseases (Noga, 
2010). The bacterial disease attacking catfish is commonly caused by $A$. hydrophila bacteria (Ventura and Grizzle, 1988).

The spread of the disease can be overcome through special treatments which aims to inhibit /kill the disease-causing bacteria. Currently, most of the treatments use antibotics. However, longterm use of antibiotics can lead to various problems, such as the resistance of the bacteria to antibiotics so the effect is no longer effective. Thus, an alternative to treating bacterial diseases is by utilizing natural ingredients (Levy, 1998).

One of the natural ingredients that can be utilized to treat bacterial diseases is strychnine bush ( $S$. ligustrina), commonly known as sea bidara trees. Strychnine bush contains alkaloid compounds, phenols, flavonoids, saponins, steroids, tannins and triterpenoids that are useful for preventing bacterial growth by damaging cell membranes and their ability as antibacterials. Sarmento et al. (2015) shows that at a dose of MIC 32-128 ppm, strychnine bush can inhibit bacterial growth.

For this reason, this research is essential, especially to identify the antibacterial potential of strychnine bush against $A$. hydrophila bacteria through invitro and invivo test. The use of strychnine serves as the first prevention of bacterial diseases that commonly attack fish.

\section{Material and methods}

\subsection{The extraction of Strychnine Bush.}

Strychnine bush extract was made through extraction method. The process of extraction began with maserating by soaking bush dust in methanol $90 \%$ with a ratio of 1 : 3 for $1 \times 24 \mathrm{hr}$. After that, the strychnine bush powder was macerated and filtered. Finally, it was evaporated in a rotary evaporator with a temperature of $40^{\circ} \mathrm{C}$ in $1800 \mathrm{rpm}$ to produce strychnine bush extract.

\subsection{Preparation of media natrium broth.}

$10 \mathrm{~g}$ of natrium broth medium was weighed using a digital scales and put into the erlenmeyer. Then, the media was dissolved in $300 \mathrm{ml}$ aquades and homogenized with a hotplate and magnetic stirrer. The already homogeneous media was then covered with a cotton and wrapped in aluminum foil and fastened by a string. The media was sterilized using autoclave at a temperature of $121{ }^{\circ} \mathrm{C}$ for 20 min with 1 atm pressure.

\subsection{Preparation of mueller hinton agar for test discs}

Mueller Hinton Agar ( $15 \mathrm{~g})$ media was weighed using a digital scales. The media was put into a sterile Erlenmeyer and dissolved with $370 \mathrm{ml}$ aquades then homogenized with a hotplate and magnetic stirrer. The erlenmeyer was covered with a cotton, wrapped in aluminum foil and tied with a rope. After that, the media was sterilized with autoclave at a temperature of $121{ }^{\circ} \mathrm{C}$ for 15 min with $1 \mathrm{~atm}$ pressure. After reaching medium heat, the sterile media was poured on a petri dish (approximately 5 - $10 \mathrm{ml}$ for each cup). Then, after it became solid, the media was stored in a reversed position in the refrigerator so the water vapor from the condensation on the lid would not drip. 


\subsection{Preparation of bacterial solution density $108 \mathrm{cfu} / \mathrm{mL}$ with spectrophotometer.}

The bacterial isolation of the natrium broth medium was cultured for $24 \mathrm{hr}$ at the waterbath shaker in the elenmeyer and incubated at a temperature of $27^{\circ} \mathrm{C}$ for $24 \mathrm{hr}$. The bacteria was then harvested aseptically into the falcon centrifuge tube filled with $\mathrm{NaCl}$ physiology solution. The density was calculated using a spectrophotometer with a wavelength of $\lambda 540 \mathrm{~nm}$ to obtain OD 0.235.

\subsection{Challenge Test.}

Challenge Test. After being fed with strychnine bush extract for 14 days, the catfish infected by $A$. hydrophila $108 \mathrm{cfu} / \mathrm{mL}$ bacteria was tested through soaking/dipping and being kept for 14 days.

\subsection{Prevalence.}

The prevalence of catfish was calculated after the fish was infected by $A$. hydrophila bacteria. The formula used to calculate the prevalence of the catfish is the number of infected fish divided by the number of fish observed, then multiplied by $100 \%$ (Yudhistira, 2004).

\subsection{Survival rate.}

Catfish crossing is calculated based on fish survival after bacterial infection. According to Effendie (1997), the formula used to calculate the survival rate is:

$$
S R=\frac{N t}{N 0} \times 100 \%
$$

\section{Description}

SR : Survival rate of fish (\%)

$\mathrm{Nt} \quad$ : Number of living fish in the end of the observation (tail)

No : The number of living fish in the beginning of the observation (tail)

\subsection{Data analysis}

The main parameters observed in this research are threefold, namely the width of inhibitory power, the prevalence of catfish, and the survival rate of catfish. Water quality cultivation was used as a supporting parameter. The data obtained from the observation of the research was analyzed using analysis of variance (ANAVA), followed by smallest differences test at $5 \%$ and $1 \%$.

\section{Results and Discussion}

\subsection{Bactery power test.}

The results of the disc test showed that strychnine bush extract was able to inhibit the growth of $A$. hydrophila bacteria as seen from the long clear zone. The observation of the smallest inhibitory zone diameter was obtained at $6 \%(1.79 \mathrm{~mm})$ and $30 \%(8.29 \mathrm{~mm})$ of strychnine bush extract concentration (Figure 1). This is because the active compound of strychnine bush can be dissolved 
by methanol solvent that can remove the compounds that can inhibit the growth of $A$. hydrophila bacteria with a strong inhibitory zone (susceptible bacteria).

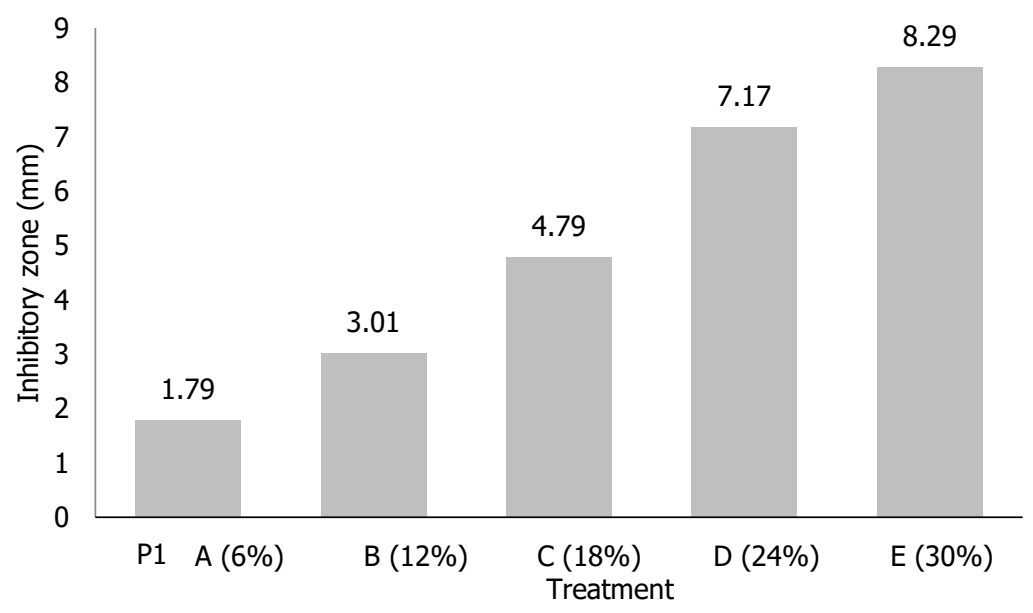

Figure 1. Diagram of Inhibitory zone

It is believed that active ingredients that plays a very important role in inhibiting the growth of $A$. hydrophila bacteria are flavonoids. According to Haryani et al. (2012), Flavonoids are the largest group of phenol compounds. Flavonoids and flavonols are synthesized in response to microbial infections. Flavonoid compounds disrupt bacterial activity by denaturing the bacterial cell protein and destroying the cytoplasmic membrane. It is supported by Brooks et al. (2005), who stated that flavonoids effectively work as bacteriostatic as it is belived to inhibit and damage the bactraria cell membranes consisting of protein layers. This inhibition and destruction of the walls and cell membranes can be accomplished by the formation of hydrogen and covalent bonds between the hydrophobic active ingredients thereby disrupting the integration of bacterial cell walls and membranes.

Based on the diagram above, it can be seen that the higher concentration of strychnine bush extract, the bigger the inhibitory power diameter is. This is because higher concentration of the extracts contains more antimicrobial active compounds so t the ability to inhibit the growth of microbes is getting higher. The data obtained was analysed using analysis of variance to determine the effect of strychnine bush extract on the inhibitory power of $A$. hydrophila bacteria. The analysis shows significant result of strychnine bush extract with methanol solvent in inhibiting $A$. hydrophila bacteria, where $\mathrm{F}$ count> $\mathrm{F}$ table $5 \%$ and $1 \%$, meaning that the use of strychnine bush extract with methanol solvent gives significantly different effect to widen the obstacle area for bacterial growth. Subsequently the smallest diffence test (BNT) was conducted to find the differences between each treatment.

The BNT test showed that A $(1.8 \mathrm{~mm})$ treatment had no significant effect on $B(3.0 \mathrm{~mm})$ treatment, but had a very significant effect on $C(4.8 \mathrm{~mm}), \mathrm{D}(7.2 \mathrm{~mm})$ and $E(8,3 \mathrm{~mm})$. In contrast, $B$ treatment $(3.0 \mathrm{~mm})$ had very significant effect from $C(4.8 \mathrm{~mm}), D(7.2 \mathrm{~mm})$ and $E(8.3 \mathrm{~mm})$ but had no significant effect on $A(1.8 \mathrm{~mm})$ treatment. The $C$ treatment $(4.8 \mathrm{~mm})$ had a very significant effect on the treatment of $D(7.2 \mathrm{~mm}), P 5(8.3 \mathrm{~mm}), A(1.8 \mathrm{~mm})$ and $B(3.0 \mathrm{~mm})$. The treatment of $D(7.2 \mathrm{~mm})$ was not significantly affected by $E(8.3 \mathrm{~mm})$ treatment but significantly affected by $A$ $(1.8 \mathrm{~mm}), \mathrm{B}(3.0 \mathrm{~mm})$ and $\mathrm{C}(4.8 \mathrm{~mm})$ treatment. 
The formation of the power zone due to the extraction of the songga tree using methanol solvent has an antibacterial active compound. According to Setiawan et al. (2014), the phytochemical contents of wood and sea lilac skin contain tannins and flavonoids. Tannin compounds can inhibit bacterial growth and kill bacteria by forming hydrogen bonds between tannins and enzyme proteins contained in the bacteria. The bacteria will be denatured so the bacterial metabolism will be disrupted. Flavonoids increase the activity of vitamin $\mathrm{C}$ as an antioxidant that prevents the oxidation of LDL cholesterol.

\subsection{Fish Prevalence.}

Prevalence is a method used to determine the percentage of sick fish from total fish examined. The results of the study on the prevalence of $A$. hydrophilla bacteria exposed to catfish (Clarias gariepinus) for 14 days resulted in different percentages (Figure 2).

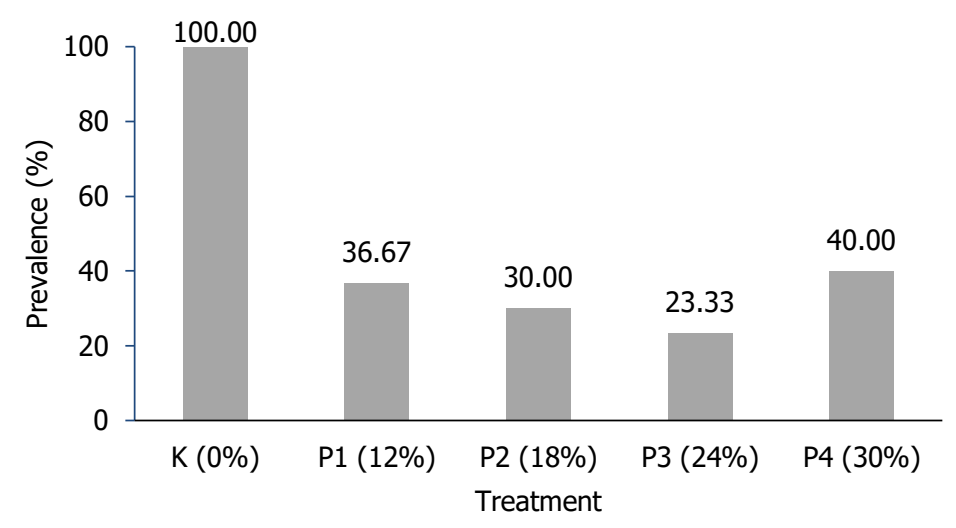

Figure 2. Diagram of the prevalence of Dumbo Catfish

Some symptoms appeared in the fish being studied include darker color of the body, slow movement, abnormal swelling of the lower abdomen, and red spots on the skin. The fish also stayed still at the bottom of the aquarium and came to the surface to breathe out. This is in line with Rahmaningsih (2016) who stated that when fish is infected by $A$. hydrophila, the clinical symptoms are apparent. In this case, the infected fish usually move more slowly and stay still at the bottom of the tank. Also, the skin bleeds and it has ulcers on the infected area. She added that bleeding may also occur in the base of the caudal fin and the dorsal fin, and the lower abdomen looks distended and swelling. Before they die, the fish will swim to the surface of the water with unstable movement.

The percentage of the prevalence in treatment P1 (12\%) was 36,7\%, P2 treatment (18\%) was $30 \%$, P3 treatment (24 \%) was $23.3 \%$, and P4 treatment (30\%) was $40 \%$. Meanwhile, the percentage of treatment $\mathrm{K}(0 \%)$ was $100 \%$. The average percentage of the catfish prevalence is presented in Figure 2. The chart above shows that control treatment has the highest prevalence because the extract of Songga wood was not given so the spread of the bacteria attacking the fish could not be inhibited. In contrast, the lowest prevalence was the $24 \%$ treatment ( $23.3 \%$.) To identify the influence of each treatment, ANOVA test was done.

The result of analysis shows that $\mathrm{F}$ arithmetic is bigger than $\mathrm{F}$ table $(0.05 \%$ and $0.01 \%)$. This indicates that $A$. hydrophilla bacteria batch test conducted for 14 days in dumbo catfish (Clarias gariepinus) had a significant effect on the prevalence of dumbo catfish. Because the result of the analysis of the different variance is real, it is necessary to do further test, namely the Real Different Difference Test (BNT). 
The BNT test result shows that treatment A (23.3\%) had no significant effect on treatment B (30\%), C (36.7\%), and D (40\%). However, it had a very significant effect on E treatment (100 $\%)$. On the other hand, treatment B (30\%) had no significant effect on treatment A (23.3 \%), C $(36.7 \%)$ and $D(40 \%)$, but showed a very significant effect on treatment $E(100 \%)$. Conversely, treatment E (100\%) had a very significant effect on treatment A (23.3\%), B (30\%), C (36.7 \%) and D (40\%).

\subsection{Survival rate.}

According to Birungi et al. (2007), survival or survival rate is the percentage of the number of cultured biota that live within a certain period of time (Figure 3).

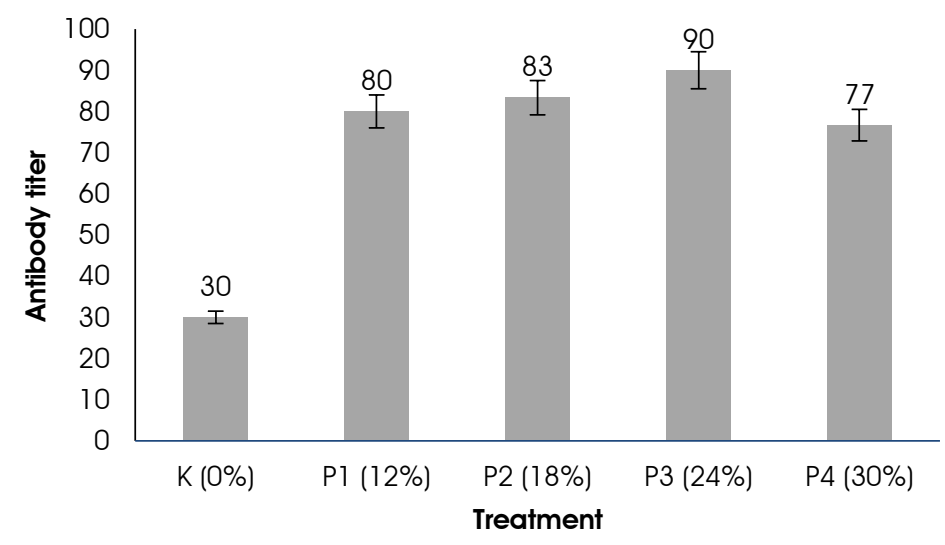

Figure 3. Diagram of antibody titer of Catfish Dumbo

The bar chart above shows the average of the synthesis on the P1 treatment of $12 \%(80 \%)$, P2 treatment of $18 \%$ (83 \%), P3 treatment of $24 \%(90 \%)$ and P4 treatment of $30 \%(77 \%)$. Whereas, $\mathrm{K}(0 \%)$ control treatment showed the average of $30 \%$ survival rate. The control treatment shows the lowest stability because during the controls teratment, the extract of strychnine bush were not given so the bacteria attacking the fish could not be inhibited. In contrast, the highest survival rate is the treatment of $24 \%$ (90\%). That being said, the optimum point for strychnine bush extract on the stability of dumbo catfish is $24 \%$ treatment.

The high survival rate of dumbo catfish in $24 \%$ treatment was probably caused by the ability of the strychnine bush extract to protect the fish immune system. According to Ciddi and Kaleab (2005), Phytochemical wood marine lava consists of alkaloids, tannins, brusin, striknin, and steroids /triterpenoids. Naturally, tannins and flavonoids can function as antioxidants. However, during 30\% treatment, there was a decrease in the survival rate of $77 \%$. It might be caused by a saponin compound in the strychnine bush. According to Alsuhendra (2013) saponins can cause poisoning in fish. It also inhibits the action of enzymes cholesterol esterase and kimotripsin in mammals and cause gill damage that leads to respiratory disturbance of fish, resulting in fish' death. To find the influence of each extract, variance analysis was done.

The results of the analysis of variance shows that $F$ count value was greater than $F$ table. It means that the strychnine bush extract given on dumbo catfish was very different from the stability of dumbo catfish. Furthermore, BNT test was carried out and showed that the use of strychnine bush extract in treatment A (30 \%) had a very significant effect on treatment B $(76.6 \%), C(83.3$ 
\%), D (86.7\%) and $\mathrm{E}(90 \%)$. While treatment $\mathrm{B}(76.6 \%)$ had very significant effect on treatment of C (83.3\%), D (86.7\%), E (90\%) and A (30.3\%), treatment C (83.3\%) was not significantly different from treatment $D(86.7 \%)$ and $E(90 \%)$, but was very different from treatment $A(30 \%)$ and $\mathrm{B}(76.6 \%)$.

\subsection{Water quality.}

Temperature in cultivation activities is very important because the temperature can affect the growth of fish. According to Cholik et al. (2005), water temperature affects the physiological processes of aquatic organisms such as respiration, metabolism, food consumption, growth, behavior, reproduction, detoxification speed and bioaccumulation and survival. Temperature measurement in this research was ranging between $23-28{ }^{\circ} \mathrm{C}$. It seemed to be a good temperature in fish culture because this is supported by Hernowo and Suyanto (2010) who found that the best water temperature for fish is between $23-32{ }^{\circ} \mathrm{C}$.

Dissolved oxygen also has an important role in the fish farming. In this study, DO yields ranged from 6.7 to $8.0 \mathrm{mg} / \mathrm{l}$. This is a perfect measurement, following Jobling (2010) advice that the amount of oxygen concentration for catfish should not be less than $3 \mathrm{mg} / \mathrm{l}$. Catfish can live in the water with low level of oxygen, because it has an additional respiratory system called arborescent.

The degree of acidity $(\mathrm{pH})$ plays an important role in fish culture because it impacts on on both the growth and reproduction of the fish. If the water $\mathrm{pH}$ is not at optimal level, then the fish will easily get stressed and get sick. Also, it will affect the fish reproductive system and growth. Barus (2002) states that the ideal water pH for aquatic organisms is between 7-8.5. The water pH in this study was between 6.3-7.2.

\section{Conclusions}

Strychnine bush extract with different concentrations significantly inhibited the growth of $A$. hydrophila bacteria that attacked the dumbo catfish, shown by the formation of clear zones on agar media. The concentration of strychnine bush extract that gave $A$. hydrophila bacterial inhibitory power is at a concentration of $30 \%$ with an inert power width of $8.29 \mathrm{~mm}$. The concentration of strychnine bush extract which leads to the lowest prevalence of catfish is the concentration of $24 \%$ with the prevalence of $23.3 \%$, while the highest percentage of catfish survival rate is at $24 \%$ concentration with $90 \%$ on survival rate.

\section{References}

Alsuhendra R. 2013. Bahan toksik dalam Makanan. Bandung: PT. Remaja Rosdakarya. Barus TA. 2002. Pengantar limnologi. Universitas Sumatera Utara. Medan, 193.

Birungi Z, Masola B, Zaranyika M, Naigaga I, Marshall B. 2007. Active biomonitoring of trace heavy metals using fish (Oreochromis niloticus) as bioindicator species. The case of Nakivubo wetland along Lake Victoria. Physics and Chemistry of the Earth, Parts A/B/C. 32: 1350-1358.

Brooks GF, Butel JS, Morse SA. 2005. Medical Microbiology. Mc Graw Hill, New York

Cholik F, Jagatraya AG, Poernomo R, Jauzi A. 2005. Akuakultur tumpuan harapan masa depan bangsa. Kerjasama antara Masyarakat Perikanan Nusantara (MPN) dengan Taman Akuarium Air Tawar (TAAT) Taman Mini Indonesia Indah. Penerbit PT. Victoria Kreasi Mandiri. pp. 184189.

Ciddi V, Kaleab A. 2005. Antioxidants of plant origin. Indian J. Nat. Prod. 21: 3. 
Effendie. 1997. Biologi perikanan. Yayasan Pustaka Nusatama: Yogyakarta. pp 163.

Haryani A, Grandiosa R, Buwono ID, Santika A. 2012. Uji efektivitas daun pepaya (Carica papaya) untuk pengobatan infeksi bakteri Aeromonas hydrophila pada ikan mas koki (Carassius auratus). Jurnal Perikanan Kelautan. 3.

Hernowo AP, Suyanto SR. 2010. Pembenihan dan Pembesaran Lele. Penebar Swadaya.

Jobling M. 2010. RR Stickney: Aquaculture: An introductory text. Springer.

Levy SB. 1998. The challenge of antibiotic resistance. Scientific American. 278: 46-53.

Noga EJ. 2010. Fish disease: diagnosis and treatment, John Wiley \& Sons.

Rahmaningsih S. 2016. Hama dan Penyakit Ikan. Deepublish. Yogyakarta, 352.

Sarmento dCN, Worachartcheewan A, Pingaew R, Prachayasittikul S, Ruchirawat S, Prachayasittikul V. 2015. Antimicrobial, antioxidant and anticancer activities of Strychnos lucida R. Br. African Journal of Traditional, Complementary and Alternative Medicines. 12: 122-127.

Setiawan O, Wahyuni N, Susila WW, Rahayu AAD, Rostiwati T. 2014. Bidara laut (Strychnos ligustrina Blume) syn. S. Iucida R. Br: Sumber Bahan Obat Potensial di Nusa Tenggara Barat dan Bali. Bogor: Forda Press. ISBN, 978-602.

Shrestha MK, Pant J. 2012. Small-scale aquaculture for rural livelihoods: Proceedings of the Symposium on Small-scale aquaculture for increasing resilience of Rural Livelihoods in Nepal. 5-6 Feb 2009. Kathmandu, Nepal, WorldFish.

Ventura M, Grizzle J. 1988. Lesions associated with natural and experimental infections of Aeromonas hydrophila in channel catfish, Ictalurus punctatus (Rafinesque). Journal of Fish Diseases. 11: 397-407.

Yudhistira E. 2004. Ektoparasit Crustacea pada Ikan Kerapu Merah (Plectropomus sp.) dari kepulauan Pangkajene perairan Barat Sulawesi Selatan.[Skripsi]. Bogor: Institut Pertanian Bogor. 